\title{
Potential impact of future climate change on maize (Zea mays $L$.) under rainfed condition in central India
}

\section{ROHIT PATIDAR ${ }^{1}$, M. MOHANTY ${ }^{1}$, NISHANT K. SINHA ${ }^{1 *}$, S.C. GUPTA ${ }^{2}$, J. SOMASUNDARAM ${ }^{1}$, R.S. CHAUDHARY ${ }^{1}$, R. SOLIYA ${ }^{1}$, K.M. HATI ${ }^{1}$, M. PRABHAKAR ${ }^{3}$, K. SAMMI REDDY ${ }^{3}$, A.K. PATRA $^{1}$ and SRINIVAS RAO CH. ${ }^{4}$}

\author{
${ }^{1}$ ICAR-Indian Institute of Soil Science, Bhopal, Madhya Pradesh, India; ${ }^{2}$ R.A.K College of Agriculture, Sehore, Madhya \\ Pradesh, India; ${ }^{3}$ ICAR-Central Research Institute for Dryland Agriculture, Hyderabad, Telangana, India; ${ }^{4}$ ICAR-National \\ Academy of Agricultural Research Management, Hyderabad, Telangana, India \\ *Corresponding author's email: nishant.sinha76211@gmail.com
}

\begin{abstract}
A simulation experiment was carried out using Agriculture Production Systems Simulator (APSIM) model to assess the impact of climate change (change in temperature and rainfall patterns) on productivity of maize in the state Madhya Pradesh. Thirty districts with 74 soil profiles from Madhya Pradesh state were considered for the study. However, we are presenting the average results over districts and soil profiles. A well-parameterised and validated APSIM model was used to simulate the effects of temperature and rainfall on maize grain and biomass yield. Increase in temperature having negative effects on both grain and biomass yield of maize. While increasing the temperature from base to $5{ }^{\circ} \mathrm{C}$, the grain and biomass yield of maize decreased by $40 \%$ and $28 \%$, respectively. Further, increasing the temperature by $1{ }^{\circ} \mathrm{C}$ could reduce the grain and biomass yield by $10 \%$ and $8 \%$, respectively. A small increase in maize yield was observed by $10 \%$ decrease of rainfall from the base. While rainfall increase by $10 \%$ or more and decrease by $>20 \%$ would results in lower maize yield and biomass. The decrease in maize yield due to increase in temperature could be attributed to decrease in duration of the crop. One-degree increase in temperature may decrease the duration of crop by 4.3 days. This study also revealed that agronomic management practices such as delaying of sowing dates could reduce the impact of climate change on crop yield to a considerable extent. By adopting the sowing date between $7^{\text {th }}$ and $14^{\text {th }}$ July, it may be possible to reduce the impact of temperature change on maize grain and biomass yield in central Indian condition.
\end{abstract}

Key words: Maize, climate change, rainfed, central India

Maize (Zea mays L.) is one of the most versatile crops owing to wider adaptability under diverse agro-climatic conditions. Worldwide, it is cultivated on nearly $150 \mathrm{mha}$ in about 160 countries, representing diverse soil, climate, biodiversity, and management practices, and contributes $\sim 36 \%$ (782 million tonnes, $\mathrm{mt}$ ) of global grain production (Singh et al., 2017). In India, maize is the third largest staple food crops in terms of area and contributes nearly $9 \%$ in the national food basket. The predominant maize growing states that contributes more than $80 \%$ of the total maize production are Andhra Pradesh (20.9\%), Karnataka(16.5\%), Rajasthan (9.9\%), Maharashtra (9.1\%), Bihar (8.9\%), Uttar Pradesh (6.1\%), Madhya Pradesh (5.7\%), and Himachal Pradesh (4.4\%) (Murdia et al., 2016). Maize is one of the promising options for diversifying agriculture in upland areas of India. The area under maize cultivation in India has gradually expanded over the past few years to about 9.19 million ha in 2014-2015 and produces 24.17 mt (Anonymous, 2016).

The change in climate in terms of rainfall variability and temperature fluctuation projected to have significant impacts on agricultural production (Battude et al., 2016). Worldwide, researchers agree that anthropogenic emissions of greenhouse gases lead to accelerating climate change and their impact on agriculture sector at the local, regional and global scales (Li et al., 2014). The impact of climate change on agriculture vary through the latitudes and from crop to crop (Msowoya et al., 2016). Higher temperatures can reduce crop production in many parts of the world (Gohari et al., 2013) although crop yield could increase in temperate region of the world (Chavas et al., 2009).

Nevertheless, the majority of the past studies have generally reported that negative impact of climate change on crop production (McDermid et al., 2016; Mohanty et al., 
2017a). The risks to adverse effects of climate change are expected to be highest in developing countries, particularly in sub-Saharan Africa, South and South-East Asia (Stevens and Madani, 2016). South Asia is projected to experience a warming of $2-6{ }^{\circ} \mathrm{C}$ by the end of the $21^{\text {st }}$ century (Ravindranath, 2007). South Asian countries including India are very vulnerable to the climate change by various reasons: due to its geo-climatic conditions, socio-economicdemographic backgrounds, overwhelming dependence on agriculture and rural sectors for livelihoods, etc. (Islam et al., 2009). India's surface temperature is presently increasing at $0.08^{\circ} \mathrm{C}$ per decade. Such increase in temperature causes a drastic decline in the agricultural output, exacerbating the problems of food insecurity and rural poverty (Birthal et al., 2014). Allen et al. (2003) have shown that $1^{\circ} \mathrm{C}$ increase in mean annual temperature will reduce productivity by $17 \%$ in maize and soybean in south Asian region. Similarly, in central India, Mohanty et al. $(2015,2017 b)$ reported a decline in soybean and wheat yield by $10 \%$ and $8 \%$, respectively by $1{ }^{\circ} \mathrm{C}$ increase in temperature. Thus, assessments and understanding of the possible impacts of climate change on crop in a particular geographical region are essential as they can lead to site-specific recommendations to take advantage of the potential benefits and minimize potential adverse impacts of climate on crop production.

Climate change may drasticallymodify precipitation, temperature, soil water, runoff, and may reduce crop maturation period and increase yield variability and could reduce areas suitable for the production of many crops (Olesen and Bindi, 2002). In the context of climate change impacts, the contribution of rainfed agriculture for food security should not be underestimated as it currently supplies some $44 \%$ of food grains and supporting $40 \%$ of the population in India. In central India, particularly in Madhya Pradesh, maize is mostly grown as rainfed crop, and its productivity tends to be affected by unpredictable climatic scenarios. In a world where the population is continuously increasing, it is necessary to maintain sufficient levels of crop production to ensure food security in changing climate scenarios. Therefore, this study was aimed to evaluate and assess the possible impacts of climate change on maize production in rainfed region of central India and develop adaptation strategies measures to offset its adverse impact.

\section{MATERIALS AND METHODS}

\section{Study area}

This study was conducted over Madhya Pradesh

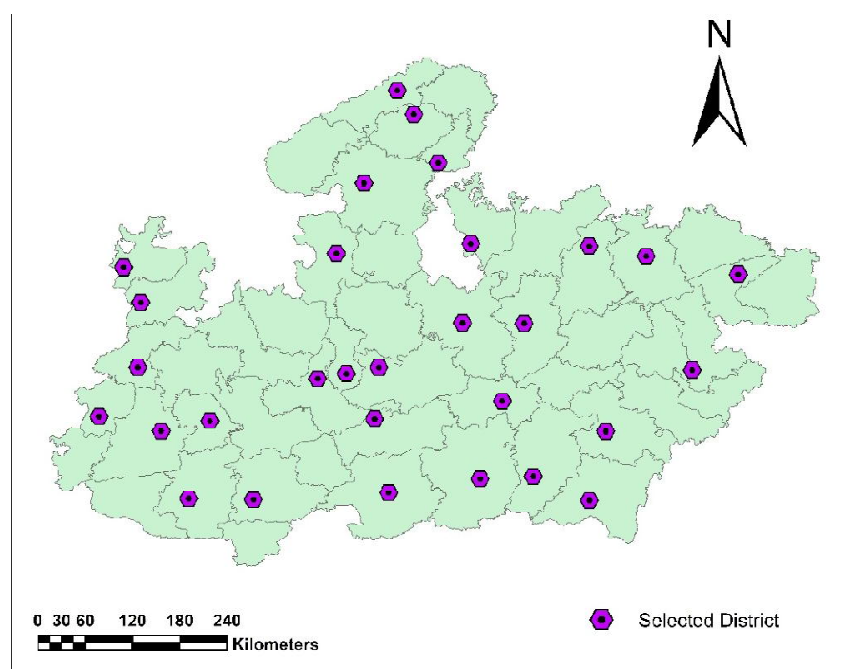

Fig. 1: Location map of the study area

state, which is geographically located between latitude $21.2-26.87^{\circ} \mathrm{N}$ and longitude $74^{\circ} 59^{\prime}-82^{\circ} 06^{\prime} \mathrm{E}$. The state administratively divided into 51 districts, out of this, 30 districts were selected for this study (Fig. 1). The mean minimum and maximum temperature for 31 years vary among selected districts are $17.2-21.4{ }^{\circ} \mathrm{C}$ and $30.4-34.8{ }^{\circ} \mathrm{C}$, respectively. The long-term annual average precipitation varies between 755-1487 mm within the study area. The dominant soil types of the study area are Vertisols, Inceptisols, and Entisols. The sand, silt, and clay content were varied between $5 \%-79 \%, 3 \%-37 \%$, and $15-70 \%$, respectively within the study region. The soil-water characteristic such as permanent wilting point and field capacity of different locations are in the range of $11-33 \%$ and $19-52 \%$, respectively. While the bulk density varies from 1.19 to 1.61 $\mathrm{Mg} \mathrm{m}^{-3}$.

\section{Climatic Scenarios}

The long-term (1980-2010) baseline data that included minimum and maximum temperatures, daily precipitation for different locations of Madhya Pradesh state were obtained from India Meteorological Department (IMD), Pune. Gaps in meteorological data point were filled with data from the NASA prediction of world wide energy resources (https://power.larc.nasa.gov/). In this study, simulations of future climate scenarios were based upon the observed baseline climate. For simulating future climate scenarios in line with different representative concentration pathway (RCP), the stepwise increment of $0.5^{\circ} \mathrm{C}$ up to $5^{\circ} \mathrm{C}$ and deviations in rainfall from $-30 \%$ to $+30 \%$ over the baseline climate were considered in the model itself. This ranges utmost covers the estimation of RCPs for the study area (Mohanty et al., 2017a,b). In this study, the ' $\mathrm{CO}_{2}$ 
fertilizer effect' is assumed to have no enhancing effect on maize output as the interaction of carbon dioxide with other environmental variables remains uncertain and continues to be debated among scientists.

\section{Crop simulation model: Model calibration and validation, and crop management practices}

Crop models such as Agricultural Production Systems sIMulator (APSIM) are tools for translating the climate information together with soil, and crop management practices into crop yield. The APSIM is a modular modelling framework, has the capability to simulate yield and biomass of different crops. In this study, APSIM model was applied to simulate maize yield and biomass under different climatic scenarios over the Madhya Pradesh state. Experimental data from the research farm of ICAR-Indian Institute of Soil Science, Bhopal were used to calibrate and evaluate the model, so that model parameters truly represent crop responses to soil and atmospheric conditions, and management practices within the study region. APSIM model calibration and some of the validation results for the maize crop in the same study region have been presented in Mohanty et al. (2017a). However, model was further validated using leaf area index (LAI) and maize biomass to exhibit model capabilities to predict these variables. Following climate, management, and soils of all selected districts of the state were put as input in the APSIM to simulate maize yield and biomass under different climatic scenarios. The soil information of different locations was taken from soils of Madhya Pradesh (NBSS \& LUP, 1999). Further, the model was instructed to sow maize on $30^{\text {th }}$ June of every year. The plant population, sowing depth and row spacing was set as eight plants $\mathrm{m}^{-2}, 50 \mathrm{~mm}$ and $600 \mathrm{~mm}$, respectively. The nitrogenous fertilizer was applied as urea nitrogen form@120 N kg ha ${ }^{-1}$ in the model, which is a common practice in the study area.

\section{RESULTS AND DISCUSSION}

\section{Validation of maize cultivar}

The APSIM maize module was validated using periodic leaf area index (LAI) and maize biomass data. Three statistical parameters viz coefficient of determination $\left(\mathrm{R}^{2}\right)$, root mean square error (RMSE) and model efficiency (ME) were used to perform the validation test. Higher value of $\mathrm{R}^{2}$ (for $\mathrm{LAI}=$ 0.74 and biomass $=0.91$ ), $\mathrm{ME}$ (for $\mathrm{LAI}=0.89$ and biomass $=0.99$ ) and lower value of RMSE (for $\mathrm{LAI}=0.30 \mathrm{~m}^{2} \mathrm{~m}^{-2}$ and biomass $=173 \mathrm{~kg} \mathrm{ha}^{-1}$ ) shows validation results are quantitatively good and show a close relation between simulated and observed LAI and biomass (Fig. 2a,b). However, the differences between observed and predicted values may be attributed to the variability in the field experimentation.

\section{Impacts of elevated temperatures on maize yield and biomass}

The simulated results showed that maize yield and biomass decreased under the influence of higher temperature. The increase in temperature by $1{ }^{\circ} \mathrm{C}$ from baseline resulted in a decrease in grain and biomass by $9.5 \%$ and $8.1 \%$, respectively (Fig $3 \mathrm{a}, \mathrm{b}$ ). Further, an increase of $5^{\circ} \mathrm{C}$ from baseline temperature resulted in $36.9 \%$ and $27.7 \%$ decreased in grain and biomass, respectively, over the Madhya Pradesh state. Several studies showed that the grain yields of maize crops continue to decrease due to projected higher temperature during remainder of $21^{\text {st }}$ century (Travasso et al., 2009; Hatfield et al., 2011; Lobell et al., 2011). The increased temperature induces stress during crop growing season that adversely affects plant growth, pollination, and reproductive processes (Sacks and Kucharik, 2011). However, as air temperatures rise beyond the optimum level, instead of falling at a rate commensurate with the temperature increase, crop yield losses accelerate (Hatfield and Prueger, 2015). Meza and Silva (2009) attributed the reduction in yield to the shortening of the growth period of maize under the elevated temperature. It is also reported that temperature beyond $30^{\circ} \mathrm{C}$ induces pollen shedding much ahead of silks emergence, while silking is delayed so that silking period does not match to anthesis/ tasselling stage, resulting in poor synchronization of flowering (asynchrony). Further, rise in temperature reduces the pollen viability and silk receptivity resulting in poor seed set and reduced yield (Shreshta et al., 2015). The high temperature also leads to embryo abortion in maize, which is related to the inhibition of photosynthesis which results in reduction in assimilates available for kernel development (Sehgal et al., 2018).

\section{Impacts of rainfall variability on maize yield and biomass}

Maize yield and biomass are also influenced by rainfall amount and distribution pattern. It was observed that the maize grain and biomass yield increased with decrease in rainfall to $10 \%$ and $20 \%$ from the baseline. Further decrease in the rainfall to $30 \%$, the maize grain, and biomass yield decreased by $9 \%$ and $6 \%$, respectively. However, increase in rainfall from the base lead to decrease in maize grain and biomass yield. There was $10 \%$ decrease in grain and biomass yield by increasing the rainfall to $30 \%$. Rainfall variability from season to season significantly affects soil water availability to crops, and thus pose adverse effect on crop 

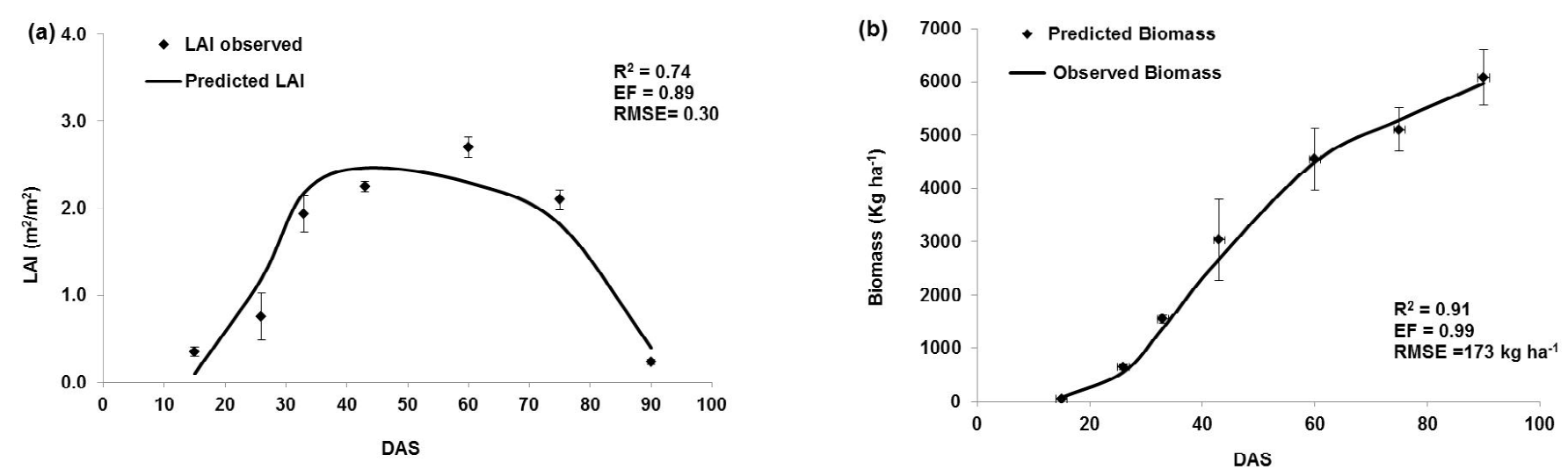

Fig. 2: Validation of APSIM model for Maize cultivar (Kanchan-101) showing observed and predicted (a) leaf area index (LAI) and (b) biomass
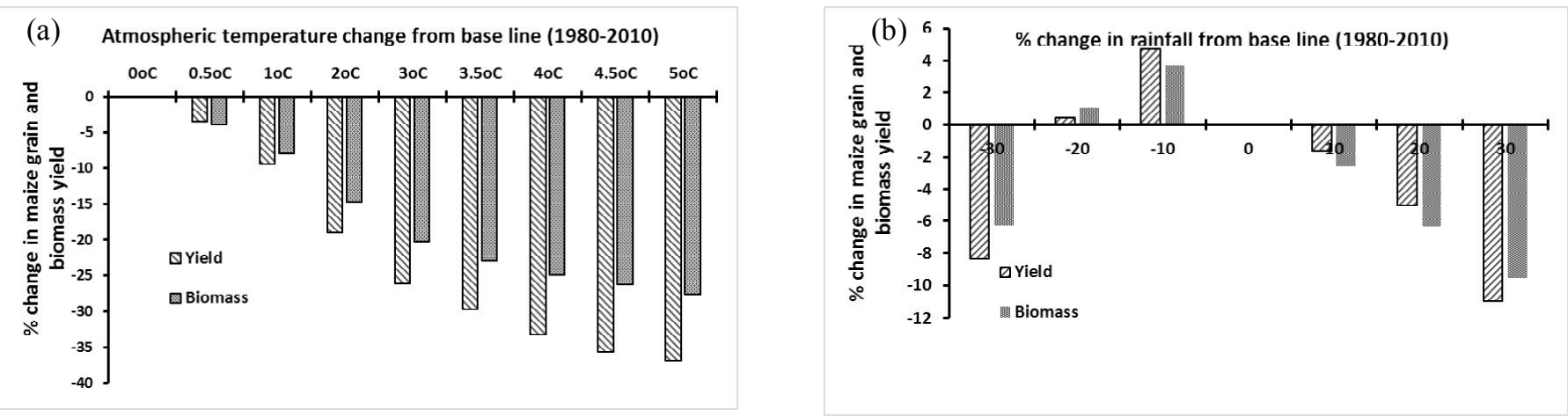

Fig.3: Effect of change in (a) temperature and (b) rainfall on maize yield and biomass
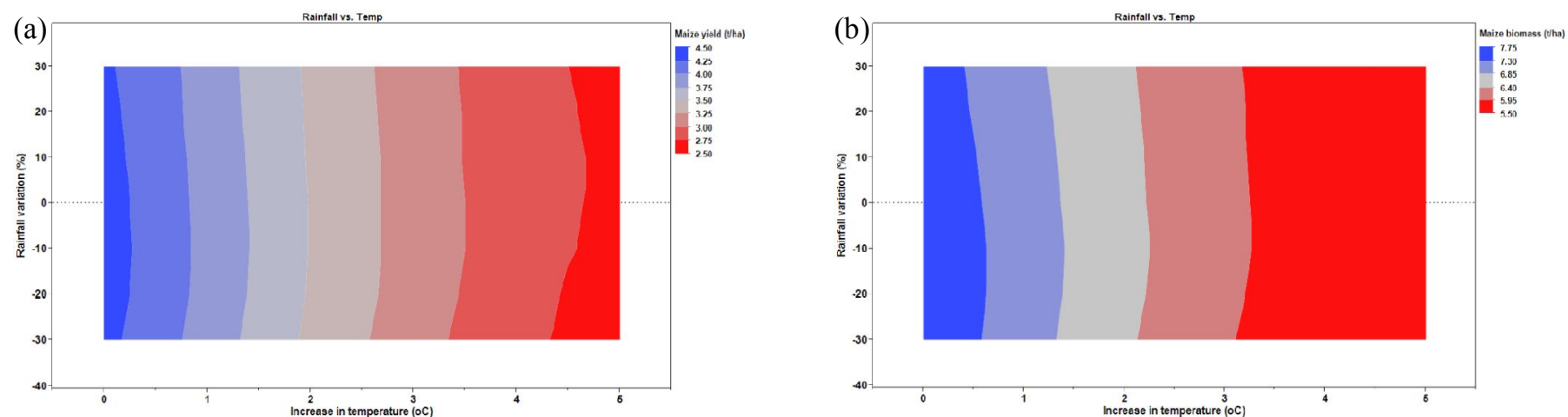

Fig. 4: Interaction effect of change in temperature and rainfall on maize yield and biomass $\left(\mathrm{t} \mathrm{ha}^{-1}\right)$

production. Omoyo et al. (2015) mentioned that maize crop is very sensitive to water availability during its critical period i.e. from flowering to beginning of grain filling, due to high water requirement, in terms of evapotranspiration and high physiological sensitivity when determining its main yield components such as the number of ears per plant and number of kernels per ear. A usual maize crop requires $700 \mathrm{~mm}$ rain to complete the life cycle with good production. Increase of decrease from the $700 \mathrm{~mm}$ of rainfall will adversely affect the crop growth and yield. In our study site, rainfall varies between $755-1487 \mathrm{~mm}$, which leads to increase in maize yield by $10 \%-20 \%$ decrease in rainfall. However, increase in rainfall from the baseline resulted in reduction in crop growth and yield. The reason could be that most of the study area receives a decent amount of rainfall, which is sufficient for field crops in any regular season. However, further increasing the rainfall will provide a negative impact as studied from the simulation of the maize crop.

\section{Interactive effect of temperatures $\times$ rainfall on maize yield and biomass}

The interaction effect of change in temperature and rainfall on maize yield and biomass were also quantified 
Table 1: Effect of change in date of sowing on maize yield with temperature change

\begin{tabular}{lllll}
\hline Date & \multicolumn{4}{c}{ Temperature Changes } \\
& $1{ }^{\circ} \mathrm{C}$ & $2{ }^{\circ} \mathrm{C}$ & $3{ }^{\circ} \mathrm{C}$ & $4{ }^{\circ} \mathrm{C}$ \\
\hline 22 June & 11 & 20 & 27 & 30 \\
30 June & 8.1 & 15 & 20 & 25 \\
07 July & 7.5 & 12 & 16 & 20 \\
14 July & 7.0 & 10 & 14 & 18 \\
21 July & 12 & 18 & 22 & 26 \\
31 July & 15 & 25 & 32 & 37 \\
\hline
\end{tabular}

using the APSIM model. The results of this analysis are given in Fig. 4 a\&b. The maize yield and biomass at a given temperature did not vary much with variation in rainfall $( \pm$ 10 to $30 \%$ ). It showed that effect of rainfall had less impact on maize grain and biomass yield than temperature. Lobell and Burke (2008) have also found that uncertainties related to temperature have higher significant contribution to climate change impact than precipitation.

\section{Adaptation strategies}

The increased temperature to the tune of $1^{\circ} \mathrm{C}$ resulted in the reduction in grain yield by $8 \%$ when the sowing date of maize was the $30^{\text {th }}$ June (Table 1 ). However, by advancing the sowing date beyond the $30^{\text {th }}$ of June, i.e. $7^{\text {th }}$ July and $14^{\text {th }}$ July, it was observed that the reduction in yield was in the range of 7.5 to $7 \%$ from the normal. Therefore, by adopting the sowing date between $7^{\text {th }}$ to $14^{\text {th }}$ July can possibly reduce the impact of temperature change on maize yield. Sowing after the $21^{\text {st }}$ July did not have any mitigating effect due to temperature change on maize yield. A similar trend in reduction in grain yield of maize was observed when the temperature increased by 2,3 and $4{ }^{\circ} \mathrm{C}$. So, sowing in between $7-14$ July was found to be a good adaptive strategy to combat the adverse impact of climate change. Similar results have also been reported for rice, wheat and soybean crops (Jalota et al., 2012; Balvanshi and Tiwari, 2019). Offsetting the effect of climate change through delaying sowing dates is mainly due to shift of crop water requirement, which is in tune with the peak of seasonal rainfall. This would lessen exposure to drought during silking- tasseling stage and provide some escape from the observed and projected warming concentrated mainly during the early part of crop growth.

\section{CONCLUSION}

In this study, APSIM model was used to quantify the potential impact of future climate change on maize grain and biomass yield under rainfed conditions in central India. The study showed that increasing the temperature by $1{ }^{\circ} \mathrm{C}$ might reduce the maize grain and biomass yield by $10 \%$ and $8 \%$, respectively. Increase in rainfall also resulted in decrease in maize yield and biomass. It was also found that agronomic management practices such as advancing the sowing dates could reduce the impact of climate change on crop yield to a considerable extent.

\section{REFERENCES}

Allen, L.H., Pan, D., Boote, K.J., Pickering, N.B. and Jones, J.W. (2003). Carbon dioxide and temperature effects on evapotranspiration and water use efficiency of soybean. Agron. J., 95: 1071-1081.

Anonymous (2016). http://ficci.in/spdocument/22966/IndiaMaize-Summit.pdf

Balvanshi, A. andTiwari, H.L. (2019). Mitigating future climate change effects on wheat and soybean yields in central region of Madhya Pradesh by shifting sowing dates. $J$. Agrometeorol., 21(4): 468-473.

Battude, M., AlBitar,A., Morin, D., Cros, J., Huc, M., Sicre, C. M., Le Dantec, V. and Demarez, V. (2016). Estimating maize biomass and yield over large areas using high spatial and temporal resolution Sentinel-2 like remote sensing data. Remote Sens. Environ., 184: 668-681.

Birthal,P.S., Khan, T., Negi, D.S. andAgarwal, S. (2014). Impact of climate change on yields of major food crops in India: Implications for food security. Agric. Eco. Rev., 27(2): 145-155.

Chavas, D.R., Izaurralde, R.C., Thomson, A.M. and Gao, X. (2009).Long-term climate change impacts on agricultural productivity in eastern China. Agric. Meteorol., 149:1118-1128.

Gohari,A., Eslamian, S., Abedi-Koupaei, J., Bavani,A.M., Wang, D. and Madani, K. (2013). Climate change impacts on crop production in Iran's Zayandeh-Rud River basin. Sci. Total Environ., 442: 405-419.

Hatfield, J.L., Boote, K.J., Kimball, B.,Ziska, L., Izaurralde, R.C., Ort, D., Thomson, A.M. and Wolfe, D. (2011). Climate impacts on agriculture: implications for crop production. Agron. J., 103: 351-370.

Hatfield, J.L. and Prueger, J.H. (2015). Temperature extremes: effects on plant growth and development. Weather Clim. Extrem., 10: 4-10.

Islam, A.K.M. and Sultan, S. (2009). Climate change and South Asia: What makes the region most vulnerable? https:// ideas.repec.org/p/pra/mprapa/21875.html 
Jalota, S.K., Kaur, H., Ray, S.S., Tripathi, R., Vashisht, B.B. and Bal, S.K.(2012). Mitigating future climate change effects byshifting planting dates of crops in rice-wheat cropping system. Reg. Environ. Change, 12(4): 913-922

Li, X., Takahashi, T., Suzuki, N. andKaiser, H.M.(2014). Impact of climate change on maize production in Northeast and Southwest China and risk mitigation strategies. Apcbee Procedia, 8:11-20.

Lobell, D.B. and Burke, M.B. (2008). Why are agricultural impacts of climate change so uncertain? The importance of temperature relative to precipitation. Environ. Res. Lett., 3(3): 034007-034014

Lobell, D.B., Schlenker, W. and Costa-Roberts, J. (2011). Climate trends and global crop production since 1980. Science, 333: 616-620.

McDermid, S., Gowtham, R., Bhuvaneswari, K., Vellingiri, G. and Arunachalam, L. (2016). The impacts of climate change on Tamil Nadu rainfed maize production: a multimodel approach to identify sensitivities and uncertainties. Curr. Sci., 110(7): 1257-1271.

Meza, F.J. and Silva, D. (2009). Dynamic adaptation of maize and wheat production to climate change. Climatic Change, 94(1-2):143-156.

Mohanty, M., Sinha, N.K., Hati, K.M., Reddy, K.S. and Chaudhary, R.S. (2015). Elevated temperature and carbon dioxide concentration effects on wheat productivity in Madhya Pradesh: a simulation study. $J$. Agrometeorol, 17(2):185-189.

Mohanty, M., Sinha, N.K., Patidar, R.K., Somasundaram, J., Chaudhary, R.S., Hati, K.M., Reddy, K.S., Prabhakar, M., Rao, S. and Patra,A.K. (2017a).Assessment ofmaize(Zea mays $L$.) productivity and yield gap analysis-using simulation modelling in subtropical climate of central India. J. Agrometeorol., 19(1): 343-346.

Mohanty, M., Sinha, N.K., Mc Dermid, S., Chaudhary, R.S., Reddy, K.S., Hati, K.M., Somasundaram, J., Lenka, S., Patidar, R.K., Prabhakar, M., Rao, S. and Patra, A.K. (2017b). Climate change impacts vis-à-vis productivity of soybean in vertisol of Madhya Pradesh. $J$. Agrometeorol., 19(1):10-16.

Msowoya, K., Madani, K., Davtalab, R., Mirchi, A. and Lund, J.R. (2016).Climate change impacts on maize production in the warm heart of Africa. Water Resour. Manage., 30(14): 5299-5312.

Murdia, L.K., Wadhwani, R., Wadhawan, N., Bajpai, P. and Shekhawat, S. (2016). Maize utilization in India: An Overview. A. J. Food Nutr., 4(6): 169-176.

Olesen, J. and Bindi, E.M. (2002). Consequences of climate change for European agricultural productivity, land use and policy. Eur. J. Agron., 16: 239-262.

Omoyo, N.N., Wakhungu, J. and Otengi, S. (2015). Effects of climate variabilityon maizeyield in the arid and semi-arid lands of lower eastern Kenya. Agric. Food Security, 4(1): 8 .

Ravindranath, N.H. (2007). Forests in India-Take action now, in The Hindu Survey of the Environment, The Hindu, Special Issue, New Delhi

Sacks, W.J. and Kucharik, C.J.(2011). Crop management and phenology trends in the U.S. corn belt: Impacts on yields, evapotranspiration and energy balance. Agric. For Meteorol., 151:882-894.

Sehgal, A., Sita, K., Siddique, K.H., Kumar, R., Bhogireddy, S., Varshney, R.K., HanumanthaRao, B., Nair, R.M., Prasad, P.V. and Nayyar, H. (2018). Drought or/and heat-stress effects on seed filling in food crops: impacts on functional biochemistry, seed yields, and nutritional quality. Front. Plant Sci., 9: 1705.

Shrestha, J., Koirala, K., Katuwal, R., Dhami, N., Pokhrel, B., Ghimire, B.,Prasai, H., Paudel, A. and Pokhrel, K. (2015). Performance evaluation of quality protein maize genotypes across various maize production agro ecologies of Nepal. J. Maize Res. Dev., 1(1): 21-27.

Singh, N.N. (2017) Retrospect and prospect of doubling maize production and farmers' income paper. Trust for advancement of agricultural sciences, Pusa Campus, New Delhi.

Stevens, T. and Madani, K. (2016). Future climate impacts on maize farming and food security in Malawi. Scientific Rep., 6: 36241.

Travasso, M.I., Magron, G.O., Rodrigues, G.R., Solman, S. and Nuñez, M. (2009). Climate change impacts on regional maize yields and possible adaptation measures in Argentina. Int. J. Global Warm., 1: 201-213. 